\section{A formação do pensamento político de Marx: crítica a Hegel, emancipação humana e fim do estado}

Vinícius dos Santos ${ }^{1}$ Doutor em Filosofia UFSC -SP

Resumo: $\mathrm{O}$ artigo investiga os trabalhos iniciais de Marx, procurando reconstruir o movimento de formação de seu pensamento político, primeiro passo de constituição do materialismo histórico. Para tanto, toma-se como ponto de partida a crítica marxiana à Filosofia do Direito de Hegel, mais precisamente, à forma como este filósofo concebe a relação entre Estado e sociedade civil. $\mathrm{Na}$ sequência, trata-se de elucidar os principais desdobramentos dessa crítica, quais sejam: o problema da emancipação humana e o fim do Estado. Ambos se articulam na perspectiva de reconciliar o indivíduo consigo mesmo, reabsorvendo a esfera política no âmbito da vida prática. Este é o sentido que o pensamento de Marx assume na sequência, aprimorando, mas jamais rejeitando essas teses iniciais.

Palavras-chave: Dialética; Estado; Marxismo; Sociedade civil.
The formation of Marx political thought: critique to Hegel, human emanciption and the end of the state

Abstract: The paper investigates the early works of Marx, seeking to rebuild the movement of formation of his political thought, the first step towards the constitution of historical materialism. Therefore, it takes as its starting point the Marxian critique of Hegel's Philosophy of Right, more precisely, how this philosopher conceives the relationship between state and civil society. Further, it aims to elucidate the main consequences of this criticism, namely: the problem of human emancipation and the end of the state. Both are linked in the perspective of reconciling the individual with himself, reabsorbing the political sphere in the practical life domain. This is the sense that Marx thought takes as a result, enhancing, but never rejecting these initial thesis.

Key-words: Civil society; Dialectics; Marxism; State. 
A formação do pensamento político de Marx: crítica a Hegel, emancipação humana e fim do estado

\section{Introdução}

A crítica política, particularmente, a análise do Estado moderno, é fundamental no trajeto de constituição do materialismo histórico. Com efeito, é a partir da rejeição à concepção de Estado em Hegel que Marx começa a desenvolver-se como pensador autônomo, estabelecendo uma determinada Weltanschaaung que permanecerá, refinada pela posterior crítica da economia política, até seus últimos escritos. Por isso, reconstruir os principais movimentos daquela crítica pode ser útil para estabelecer algumas das linhas de força mais importantes que a teoria marxiana viria a assumir.

Para bem compreender como se dá a formação da concepção política de Marx, convém preliminarmente notar que seu ataque central à tese hegeliana sobre o Estado (sintetizada na Filosofia do Direito) desdobra-se da crítica à religião esboçada pelos neo-hegelianos no início da década de 1840, notadamente por Ludwig Feuerbach.

Embora Marx assumisse a validade da ideia feuerbachiana de auto-alienação do homem como fundamento da religião, a crítica materialista daquele autor ainda mostravase insuficiente. Em linhas gerais, o erro de Feuerbach, na visão de Marx, foi o de ter acreditado que a superação do hegelianismo passava por inverter a equação idealista, ou seja, inverter, de modo imediato, os sinais da relação entre ser e pensar. Para Marx, antes, era preciso pensar o idealismo como parte da realidade, superando Hegel dialeticamente (ou seja, no sentido de uma Aufhebung). Por isso, fazia-se necessário compreender em que medida a filosofia especulativa de Hegel encontrava respaldo na vida real ao menos, na forma como ela se mostrava imediatamente.

Nesse sentido, cumpre lembrar que o concreto, para Hegel, é a vida da Ideia, da Razão, do Espírito Absoluto. O conceito e sua efetivação devem ser apreendidos em conjunto, em uma perspectiva temporal, porquanto este real efetivo, unidade da aparência e da essência, é racional.

Assim, o conhecimento não pode prescindir do conceito, mas o conceito realiza-se através do movimento de sua materialização nas expressões particulares. Contudo, a especulação filosófica demonstra que a aparência (isto é, a manifestação o particular, o existente) não é suficiente. Não se trata, bem entendido, de uma diferença pressuposta entre aparência e essência, entre o particular e o universal, entre o existir e o ser, mas de uma revelação trazida à luz pela reflexão. A especulação hegeliana revela, em todos os níveis, uma dialética de cisão e movimento de superação da cisão. $\mathrm{O}$ ser se objetiva; ao objetivar-se, negando-se, portanto, a si mesmo, revela suas insuficiências; e ao revelá-las, apresenta, igualmente, os meios de superá-las [aufheben]. Em linhas gerais, este é, para Hegel, o movimento da Cultura [Bildung], ou do Espírito.

Em outros termos, o Espírito (o sujeito real, o único sujeito para Hegel) exterioriza-se mediante o trabalho, estranha sua exteriorização, mas depois absorve esse estranhamento em si mesmo. É essa experiência de si do Espírito 
que, materializada nas ações humanas, confere, em última análise, o sentido da História. O sujeito hegeliano não é uma consciência-de-si que apreende o tempo, mas é o próprio movimento temporal da consciência no desenvolvimento de sua consciência-de-si.

Como se sabe, essa lógica, aqui informada de modo extremamente sintetizado, é transposta por Hegel para a análise do Estado, na medida em que este representa, no plano da História, a encarnação do Espírito ou da Ideia. O Estado moderno representaria o grau último do processo de auto-desenvolvimento do Absoluto, a reconciliação do Espírito consigo mesmo, pois é nele que a liberdade, enquanto seu conteúdo elementar, se realiza como universal.

É contra essa transposição que Marx inicialmente dirige sua atenção. $\mathrm{Ou}$, mais precisamente, compreender como essa transposição revela uma determinada forma de enfrentar a configuração de mundo da sociedade moderna, é o desafio a ser enfrentado já em seu primeiro grande escrito: precisamente, uma Crítica à Filosofia do Direito de Hegel.

\section{A relação entre Estado e sociedade civil: a crítica a Hegel}

Marx abre a Introdução de sua Crítica da Filosofia do Direito de Hegel (introdução escrita em 1844, após a redação do que seria o corpo da obra) asseverando que, na Alemanha, a crítica da religião havia chegado, no essencial, a seu fim (com Feuerbach). Tal constatação é relevante, porque, para Marx, "a crítica da religião é o pressuposto de toda a crítica. [...] O homem é o mundo do homem, o Estado, a sociedade" (MARX, 2005: 145) ${ }^{2}$. É precisamente a presença germinal desses pressupostos que concederá a Marx o ensejo para transitar da "crítica do céu" à "crítica da terra", antecipando, em boa medida, o sentido que seu próprio pensamento viria a assumir:

a tarefa imediata da filosofia, que está a serviço da história, é desmascarar a autoalienação bumana nas suas formas não sagradas, agora que ela foi desmascarada na sua forma sagrada. A crítica do céu transforma-se deste modo em crítica da terra, a crítica da religião em crítica do direito, e a crítica da teologia em crítica da politica (MARX, 2005:146). ${ }^{3}$

Neste diapasão, portanto, é que Marx busca apreender e superar a concepção hegeliana de Estado.

Marx concorda com a rejeição hegeliana ao atomismo social dos contratualistas ${ }^{4}-\mathrm{em}$ Hegel, o Estado organiza a vida social, essencialmente desorganizada. Ao mesmo tempo, porém, refuta o idealismo. $\mathrm{Na}$ filosofia hegeliana, o conceito "mede" o Estado existente, como forma de revelar suas deficiências ${ }^{5}$. Trata-se, portanto, de captar a dinâmica política - a relação do Estado com as esferas da família e da sociedade civil - através da análise do particular (o Estado determinado, a "cruz do presente", conforme os termos do prefácio da Filosofia do Direito) em relação ao universal (o conceito de Estado).

Esse gesto é possível porque, em Hegel, a Razão - o Absoluto - é o sujeito. Em Marx, ao inverso, ela é um predicado humano ${ }^{6}$. Destarte, é preciso denunciar a inversão tipicamente idealista das proposições hegelianas, reivindicando ao Estado a função de predicado e à família e à 
A formação do pensamento político de Marx: crítica a Hegel, emancipação humana e fim do estado

sociedade civil - ou seja, aos indivíduos - o de sujeitos da história ${ }^{7}$.

Família e sociedade civil são os pressupostos do Estado; elas são os elementos propriamente ativos; mas, na especulaşão, isso se inverte. No entanto, se a Ideia é subjetivada, os sujeitos reais, familia e sociedade civil, 'circunstâncias, arbitrio' etc. convertem-se em momentos objetivos da Ideia, irreais e com um outro significado. [...]. família e sociedade civil são partes reais do Estado, existências espirituais reais da vontade; elas são modos de existência do Estado; família e sociedade civil se fazem, a si mesmas, Estado. Elas são a força motriz: Segundo Hegel, ao contrário, elas são produzidas pela Ideia real.(MARX, 2005: 30)

Por conseguinte, "a condição torna-se o condicionado, o determinante torna-se determinado, o produtor é posto como o produto de seu produto" (MARX, 2005: 31). Contudo, essa inversão cobra um alto preço: como observa Mendes (cf. 2012: 246), denunciá-la significa dissolver toda a harmonia do sistema dialético hegeliano, que enxerga no Estado o elemento de unificação das cisões resultantes da sociedade civil [die bürgerliche Gesellschaft].

Com isto, o âmago da crítica de Marx ao pensamento político de Hegel começa a se desvelar. Para o primeiro, a análise hegeliana é correta em suas determinações, mas é lógica, e não histórica: "o conteúdo concreto, a determinação real, aparece como formal; a forma inteiramente abstrata de determinação aparece como conteúdo concreto" (MARX, 2005: 38). Com efeito, Hegel não teria percebido que sua descrição da sociedade civil diz respeito a uma forma social específica, à qual corresponde uma relação determinada com um tipo igualmente determinado de Estado. A "alma dos objetos, no caso presente, do Estado, está pronta, predestinada antes de seu corpo, que não é propriamente mais do que aparência, registrados, na 'Santa Casa' da lógica" (MARX, 2005: 36). Dito de outro modo, Hegel "dá à sua lógica um corpo político", mas não fornece "a lógica do corpo político". O "momento filosófico não é a lógica da coisa, mas a coisa da lógica. A lógica não serve à demonstração do Estado, mas o Estado serve à demonstração da lógica" (MARX, 2005: 39). ${ }^{8}$

A perspectiva hegeliana não é, porém, mero acidente teórico. Por isso, simplesmente inverter seus sinais, como fizera Feuerbach, não poderia bastar. Para Marx, a filosofia de Hegel revela a aparência necessária assumida pela sociedade moderna, isto é, a consciência de si da burguesia e de sua relação com o Estado, na qual sujeito e objeto aparecem "invertidos". Dito de outro modo, no essencial, Hegel é um reflexo correto de uma realidade falsa (invertida), fato esse que se comprovaria, dentre outras, pela percepção da autonomia do Estado frente à vida prática dos indivíduos.

Explica-se essa autonomia: em Hegel, como mencionado, a Razão resolveria (no âmbito do conceito) os problemas postos por seu movimento imanente. Ocorre ainda, porém, que a razão hegeliana, segundo Marx, encontra-se além da História: ela permite compreender a História, mas ela mesma não seria histórica. Daí que, entendido como "Ideia divina como ela existe sobre a terra" (HEGEL, 1999: 40), isto é, como "racional em si e para si” (HEGEL, 1997: 217, \$258), o filósofo pode conceder ao Estado moderno, enquanto conceito, o papel de regulador das 
contradições da sociedade civil, veículo portador de uma "vontade universal". Mas, como o próprio Hegel demonstra", essas contradições (a cisão entre a vida particular e suas necessidades e a vida social e suas exigências) são, na prática, insuperáveis nos marcos vigentes. Não por acaso, em que pesem seus esforços teóricos em sentido contrário, Hegel se veria obrigado a assumir que o Estado surge como uma potência "estranha" [entfremdet] aos indivíduos. Nesse sentido, vale demarcar que, para Marx, "o mais profundo em Hegel é que ele percebe a separação da sociedade civil e da sociedade política como uma contradição. Mas o que há de falso é que ele se contenta com a aparência dessa solução e a faz passar pela coisa mesma" (MARX, 2005: 93).

Ao prosseguir a análise, esse contentamento hegeliano se desdobra em outras direções. Assim, se o Estado hegeliano é o sujeito enquanto realidade concreta da vontade geral, esta vontade se corporifica na Constituição ${ }^{10}$. Aqui, porém, uma nova complicação se revela, a saber, "a controvérsia entre constituição representativa e a constituição estamental" (MARX, 2005: 98).

Cumpre lembrar que Hegel defendia esta última forma de constituição à luz da oposição entre o povo como uma "massa informe, uma opinião e uma vontade inorgânica, poderes maciços em face de um estado orgânico" (HEGEL, 1997: 278, \$302). Entre os extremos, apareciam os estamentos como mediação: o termo médio a ligar, no silogismo prático (político), soberano e governo, de um lado, e população, do outro. Marx, por sua vez, defende a participação, na esfera estatal, de cada indivíduo como cidadão. Em termos que remetem a Rousseau, Marx acredita que a questão política fundamental é a participação, no poder legislativo, não de "todos singularmente", mas dos "singulares como todos" (cf. MARX, 2005: 131). Ou seja, conforme esclarece Rubens Enderle, "não de todos como simples justaposição de indivíduos atomizados, mas como 'soma das diferenças', isto é, como processo de formação da vontade geral, para além dos interesses particulares que a habitam" (ENDERLE. Apud MARX, 2005: 245).

Essa posição radicalmente democrática se explica porque, segundo Marx, a realidade dos estamentos não era aquela prevista por Hegel: antes, eles se configurariam como a oposição política organizada da sociedade civil. De acordo com aquele autor, na sociedade moderna, "o elemento políticoestamental não é, precisamente, outra coisa senão a expressão fática da relação real de Estado e sociedade civil, a sua separação" (MARX, 2005: 93). Tal separação, articulada à duplicação de significados dos estamentos, não ocorrera, segundo Marx, "enquanto a organização da sociedade civil era política ou o Estado político era a sociedade civil" (MARX, 2005: 99). Quer dizer, "não significavam uma coisa no mundo social e outra no mundo político" (MARX, 2005: 99). Assim, a constituição estamental visaria combater o dualismo entre sociedade civil e Estado "por meio de uma reminiscência", pois "a distinção dos estamentos (a distinção interna da sociedade civil) adquire, na esfera política, um significado diferente daquela da esfera social" (MARX, 2005: 99).

Marx observa haver aqui uma aparente identidade - trata-se do mesmo sujeito com uma determinação essencialmente diversa. Contudo, ressalva:

na verdade, há um duplo sujeito e essa identidade ilusória (ela é já ilusória porque o sujeito real, o homem, nas 
A formação do pensamento político de Marx: crítica a Hegel, emancipação humana e fim do estado

diversas determinações de seu ser, permanece igual a si mesmo; ele não perde sua identidade; mas, aqui, o homem não é sujeito, mas sim identificado com um predicado - o estamento - e, ao mesmo tempo, afirma-se que ele, ao se encontrar nessa determinidade determinada, encontra-se então em outra determinidade; que ele, como esta limitação exclusiva, determinada, é algo diferente desta limitação) é mantida de forma artificial mediante a reflexão de que, uma vez, a distinção social dos estamentos recebe, como tal, uma determinação que deve provir unicamente da esfera política e, doutra ver, ela recebe uma determinação, na esfera política, que não deriva da esfera politica, mas do sujeito da esfera social. Para representar tal sujeito limitado, o estamento determinado (a distinção estamental), como o sujeito essencial dos dois predicados, ou para provar a identidade de ambos os predicados, estes são mistificados e desenvolvidos em uma dupla figura ilusória, indeterminada. (MARX, 2005: 99)

Destarte, a passagem assinalada por Hegel entre a sociedade civil (estamento privado) e a atividade legislativo-estamental, isto é, este "ato político", configura-se como "uma completa transubstanciação" (MARX, 2005: 94).

Por conseguinte, a oposição entre Estado e sociedade civil, que Hegel visa solucionar por meio de um silogismo lógico-dialético, torna-se insustentável: Estado e sociedade se opõem de modo irredutível porque "não podem ser mediados um pelo outro", já que são "extremos reais" (MARX, 2005: 105) ${ }^{11}$. Não se trata de uma questão lógica, mas do próprio conteúdo da realidade que se descortina à análise.
Logo, porque se está diante de uma oposição irreconciliável, tampouco é possível legitimar a tese correlata da autonomia do aparelho estatal frente à sociedade civil - e seu papel de sujeito da História.

Como se o povo não fosse o Estado real. $O$ Estado é um abstractum. Somente o povo é o concretum. E é notável que Hegel atribua sem besitação uma qualidade viva ao abstractum, tal como a soberania, e só o faça com hesitação e reservas em relação ao concretum. (MARX, 2005: 48)

Sendo assim, ao refutar a forma pela qual Hegel concebe a relação entre Estado e sociedade civil - mais precisamente: por tomar como real aquilo que não seria mais do que aparente -, Marx pode igualmente rejeitar a defesa hegeliana da monarquia, que aparecia, neste último, como corolário necessário da tese do Estado como polo de conciliação das contradições do tecido social moderno" ${ }^{12}$ : "Soberania do monarca ou do povo: eis a question" (MARX, 2005: 49).

Nesse sentido, importa destacar que, se Feuerbach enxergava o cristianismo como o enigma revelado de todas as religiões, para Marx, a democracia é a essência de toda constituição, na medida em que seria a única possibilidade de reconciliar de fato o ser humano consigo mesmo.

Na monarquia o todo, o povo, é subsumido a um de seus modos de existência, a constituição política; na democracia, a constituição mesma aparece somente como uma determinação e, de fato, como autodeterminação do povo. $\mathrm{Na}$ 
monarquia temos o povo da constituição; na democracia, a constituição do povo. A democracia é o enigma resolvido de todas as constituições. Aqui, a constituição não é somente em si, segundo a essência, mas segundo a existência, segundo a realidade, em seu fundamento real, o homem real, o povo real, e posta como a obra própria deste último. (MARX, 2005: 50)

Para Marx, a "verdadeira democracia" ( $c f$. MARX, 2005: 51) - ou o que será, na sequência da crítica da economia política, denominado comunismo -, e que se distingue da "república política" liberal ${ }^{13}$ ou o que será, na sequência da crítica da economia política, denominado comunismo passa por absorver a esfera política no âmbito da sociedade civil, ou seja, superar concretamente a cisão visualizada, em termos lógico-ideais, por Hegel. Isto porque, na democracia, o poder emana do ser social, do indivíduo social, e não do Estado; é a práxis comum expressa no Estado:

Hegel parte do Estado e faz do homem o Estado subjetivado; a democracia parte do homem e faz do Estado o homem objetivado. Do mesmo modo que a religião não cria o homem, mas o homem cria a religião, assim também não é a constituição que cria o povo, mas o povo a constituição. (MARX, 2005: 50) ${ }^{14}$

Finalmente, importa ainda sublinhar que a cisão, para Marx, não se encontra na relação entre o Estado e seu conceito, tal como defendido por Hegel, mas dentro da relação do Estado consigo mesmo. A contradição entre classes permite a uma delas se apropriar aparelho estatal para seus fins particulares, fazendo-os passar como universais. Daí a ilusão de que o Estado seria o veículo de uma pretensa "vontade geral", ao mesmo tempo em que aparece aos indivíduos como "estranho". É esta tese da cisão interna que, mais tarde, aliás, permitirá identificar o Estado especialmente como um órgão de dominação de uma classe sobre a outra ${ }^{15}$.

\section{Emancipação política e emancipação humana}

Diante do exposto na seção anterior, verifica-se que um dos aspectos relevantes da discussão inicial sobre a relação entre Estado e sociedade civil, em Marx - assim como em Hegel - diz respeito justamente à tensão entre a vida individual e a vida pública, entre o particular e o universal, entre o indivíduo membro da sociedade civil (o bourgeois) e o cidadão membro do estado (o citoyen). Mas, se no idealismo hegeliano, o conceito de Estado moderno permitia superar aquela tensão, em Marx, apenas a construção histórica de uma "verdadeira democracia" enquanto práxis comum dos "indivíduos sociais" poderia resolver.

Dessa crítica inicial, decorrem algumas consequências relevantes, tratadas por Marx em outros escritos deste período de gestação de sua teoria autônoma, e que auxiliam na compreensão do sentido que a reflexão marxiana tomaria na sequência. Sendo assim, uma breve incursão por estes textos pode ser de grande valia para o propósito deste artigo.

Por exemplo, no ensaio $A$ questão judaica, também de 1843, Marx tece uma crítica ao Estado cristão prussiano, que negava aos judeus a igualdade de direitos perante a lei. No plano teórico, suas apreciações são preferencialmente endereçadas ao "equívoco" de Bruno Bauer, para quem a negação das manifestações religiosas dos judeus seria condição para sua emancipação política. 
A formação do pensamento político de Marx: crítica a Hegel, emancipação humana e fim do estado

Segundo Marx, o erro de Bauer consiste em concentrar sua crítica somente no "Estado cristão", não a estendendo para o "Estado em geral". Bauer, atesta Marx, não investiga a relação entre o problema da emancipação política dos judeus com o problema de fundo - e no qual este se assenta - da emancipação bumana. Com efeito, Bauer não teria se dado conta daquela irreconciliável oposição entre Estado e sociedade civil, surgida após a Revolução Francesa, fruto da emancipação da sociedade burguesa frente à esfera política, e que Hegel, como anteriormente destacado, diagnosticara, mas "contentarase com a solução aparente do problema".

Porém, a exemplo do que já identificara neste último, Marx aponta que a deficiência da tese de Bauer não é indício apenas de um engano teórico, mas novamente se relacionaria à própria realidade alemã. Com efeito, diz Marx, na Alemanha, onde ainda não existia um Estado político, a questão judaica encerrava-se no âmbito de uma discussão exclusivamente teológica. $\mathrm{Na}$ França e, sobretudo, nos Estados Unidos locais onde o Estado se erguia livre das amarras religiosas -, a emancipação política perante a religião já teria se realizado: não a suprimindo a religião, mas situando-a em seu lugar de direito, fora da órbita estatal ${ }^{16}$.

Por isso, Marx enxerga a emancipação do judeu, do cristão, ou do indivíduo que professe qualquer outra fé religiosa, como a emancipação do Estado frente ao judaísmo, ao cristianismo, à religião em geral. Numa palavra, o que Bruno Bauer não teria contemplado é precisamente aquela antítese entre o interesse geral e o interesse privado, $\mathrm{o}$ divórcio entre $\mathrm{O}$ Estado político moderno e a sociedade burguesa.
Assim, a solução baueriana não se sustenta. Diante dela, Marx se pergunta: os judeus poderiam obter os chamados direitos humanos após sua emancipação política? Bauer nega tal possibilidade, já que, em nome dos "direitos gerais do homem", teriam de sacrificar seu "privilégio da fé". Marx, porém, ao rejeitar a tese de Bauer, sublinha, ao mesmo tempo, uma densa crítica aos Droits de l'homme proclamados pela Revolução Francesa:

Os droits de l'homme, os direitos bumanos, são diferenciados como tais dos droits du citoyen, dos direitos do cidadão. Quem é esse homme que é diferenciado do citoyen? Ninguém mais ninguém menos que o membro da sociedade burguesa. Por que o membro da sociedade burguesa é chamado de "bomem", pura e simplesmente, e por que os seus direitos são chamados de direitos humanos? A partir de que explicaremos esse fato? A partir da relação entre o Estado político e a sociedade burguesa, a partir da essência da emancipação política. Antes de tudo constatemos o fato de que os assim chamados direitos humanos, os droits de l'homme, diferentemente dos droits du citoyen, nada mais são do que os direitos do membro da sociedade burguesa, isto é, do homem egoista, do homem separado do homem e da comunidade. [...]. [Sua] liberdade equivale, portanto, ao direito de fazer e promover tudo que não prejudique a nenbum outro homem. $O$ limite dentro do qual cada um pode mover-se de modo a não prejudicar $o$ outro é determinado pela lei do mesmo modo que o limite entre dois terrenos é determinado pelo poste da cerca. Trata-se da liberdade do homem como mônada isolada recolbida dentro de si mesma. [...]. No entanto, o direito bumano à liberdade 
não se baseia na vinculação do homem com os demais homens, mas, ao contrário, na separação entre um homem e outro. Trata-se do direito a essa separação, o direito do indivíduo limitado, limitado a si mesmo. A aplicação prática do direito bumano à liberdade equivale ao direito bumano à propriedade privada. [...]. $O$ direito bumano à propriedade privada, portanto, é o direito de desfrutar a seu bel prazer (à son gré), sem levar outros em consideração, independentemente da sociedade, de seu patrimônio e dispor sobre ele, é o direito ao proveito próprio. Aquela liberdade individual junto com esta sua aplicação prática compõem a base da sociedade burguesa. Ela far com que cada homem veja no outro bomem, não a realização, mas, ao contrário, a restrição de sua liberdade. [...]. Portanto, nenbum dos assim chamados direitos bumanos transcende o homem egoista, o homem como membro da sociedade burguesa, a saber, como indivíduo recolbido ao seu interesse privado e ao seu capricho privado e separado da comunidade. Muito longe de conceberem o homem como um ente genérico, esses direitos deixam transparecer a vida do gênero, a sociedade, antes como uma moldura exterior ao indivíduo, como limitação de sua autonomia original. $O$ único laço que os une é a necessidade natural, a carência e o interesse privado, a conservação de sua propriedade e de sua pessoa egoísta. (MARX, 2010: 48-50)

Destarte, Marx ressalta a contradição entre a teoria (os ideias revolucionários) e prática (a sociedade real) burguesas. Ao colocar a política como simples meio, cujo fim é a manutenção da própria vida dessa sociedade, torna-se evidente a primazia do fator econômico em detrimento do político, isto é, do individual sobre o público ${ }^{17}$. Por conseguinte, o objetivo da burguesia em promover a emancipação do ser humano dos grilhões medievais se materializou com a promoção de um tipo de indivíduo (o "homem real") voltado para os seus próprios interesses. Entrementes, o ser humano emancipado politicamente continuaria a ser uma mera abstração.

Diante deste cenário, uma nova questão se impõe: como, então, seria possível promover a emancipação bumana? Marx responde nos seguintes termos:

a emancipação bumana só estará plenamente realizada quando o bomem individual real tiver recuperado para si o cidadão abstrato e se tornado ente genérico na qualidade de homem individual na sua vida empirica, no seu trabalho individual, nas suas relações individuais, quando o bomem tiver reconbecido e organizado suas 'forces propres' como forças sociais e, em consequência, não mais separar de si mesmo a força social na forma da força política. (MARX, 2010: 54)

\section{A tese da extinção do Estado}

O que a passagem por $A$ questão judaica deixa nítido é a novidade marxiana no trato da tensão, percebida e descrita por Hegel em termos especulativos, entre o indivíduo e o todo. Nesse sentido, conforme bem recupera Mendes (cf. 2012: 149), ainda no âmbito dos trabalhos marxianos iniciais, as Glosas criticas marginais ao artigo ' $\mathrm{O}$ rei da Prússia e a reforma social'. De um prussiano, de 1844 , se destacam como outro texto no qual o filósofo formula a contradição existente entre o Estado moderno e a sociedade civil burguesa, reafirmando a polarização entre emancipação política e emancipação humana tratada em $A$ questão judaica. Sua importância maior, no entanto, 
A formação do pensamento político de Marx: crítica a Hegel, emancipação humana e fim do estado

para além dessa corroboração, concentrase no fato de que nele Marx anuncia, de modo mais nítido, duas de suas teses capitais: a) a do trabalho como o fundamento ontológico do ser social; b) e a da perspectiva de extinção do Estado e da política (como "atividade alienada") em uma futura sociedade comunista.

Nas Glosas, Marx revisita a natureza do Estado e da sociedade civil em busca da raiz das moléstias da sociedade moderna e de seus possíveis antídotos, tomando como ponto de apoio um objeto concreto: a situação precária dos tecelões prussianos. A questão elementar que atravessa as Glosas pode ser resumida do seguinte modo: a causa do pauperismo é "uma falha de administração e assistência", isto é, em termos mais contemporâneos, um problema de governo? Ou se trata de uma questão "estrutural"? Ou seja: ao se ocupar da miséria inevitável que brota da própria dinâmica da sociedade civil - algo que Hegel tão bem percebera ${ }^{18}$ - seria possível ao Estado adotar outra postura senão aquela das medidas paliativas ou assistenciais?

Para Marx, todos os Estados procuram a causa do pauperismo em deficiências acidentais e intencionais da administração não se trata de um privilégio prussiano, portanto - exatamente "porque a administração é a atividade organizadora do Estado".

O Estado não pode eliminar a contradição entre a função $e$ a boa vontade da administração, de um lado, e os seus meios e possibilidades, de outro, sem eliminar a si mesmo, uma vez que repousa sobre essa contradicão. Ele repousa sobre a contradição entre vida privada e pública, sobre a contradição entre os interesses gerais e os interesses particulares. Por isso, a administração deve limitar-se a uma atividade formal e negativa, uma vez que exatamente lá onde começa a vida civil e o seu trabalho, cessa o seu poder. Mais ainda, frente à consequências que brotam da natureza a-social desta vida civil, dessa propriedade privada, desse comércio, dessa indústria, dessa rapina reciproca das diferentes esferas civis, frente a estas consequências, a impotência é a lei natural da administração. Com efeito, esta dilaceração, esta infâmia, esta escravidão da sociedade civil, é o fundamento natural onde se apoia o Estado moderno, assim como a sociedade civil da escravidão era o fundamento no qual se apoiava o Estado antigo. A existência do Estado e a existência da escravidão são inseparáveis. $O$ Estado antigo e a escravidão antiga - fracas antiteses clássicas - não estavam fundidos entre si mais estreitamente do que o Estado moderno e o moderno mundo de traficantes, hipócritas antíteses cristãs. Se o Estado moderno quisesse acabar com a impotência da sua administração, teria que acabar com a atual vida privada. Se ele quisesse eliminar a vida privada, deveria eliminar a si mesmo, uma vez que ele só existe como antitese dela. [...] Quanto mais poderoso é o Estado e, portanto, quanto mais político é um país, tanto menos está disposto a procurar no princípio do Estado, portanto no atual ordenamento da sociedade, do qual - Estado é a expressão ativa, autoconsciente e oficial, o fundamento dos males sociais e a compreender-lhes o principio geral. $O$ intelecto político é político exatamente na medida em que pensa dentro dos limites da política. Quanto mais agudo ele é, quanto mais vivo, tanto menos é capaz de compreender os males sociais (MARX, 1995: $s / p)$. 
Logo, o próprio Estado não seria, na visão de Marx, suficientemente potente para alterar os problemas sociais intrínsecos à sociedade civil, isto é, à economia de tipo capitalista e ao modo de vida burguês que a ela se articula. Por isso, assevera, apenas uma "revolução política com alma social" poderia desvelar a diferença radical entre a emancipação política (parcial, insuficiente) e a emancipação humana integral.

Uma revolução social se situa do ponto de vista da totalidade porque - mesmo que aconteça apenas em um distrito industrialela é um protesto do homem contra a vida desumanizada, porque parte do ponto de vista do indivíduo singular real, porque a comunidade, contra cuja separação o indivíduo reage, é a verdadeira comunidade do bomem, é a essência bumana ${ }^{19}$. Ao contrário, a alma política de uma revolução consiste na tendência das classes politicamente privadas de influência a superar o seu isolamento do Estado e do poder. O seu ponto de vista é aquele do Estado, de uma totalidade abstrata, que subsiste apenas através da separação da vida real, que é impensável sem o antagonismo organizado entre a ideia geral e a existência individual do homem. Por isso, uma revolução com alma politica organiza também, de acordo com a natureza limitada e discorde dessa alma, um círculo dirigente na sociedade às custas da sociedade. Gostariamos de confidenciar ao "prussiano" o que é "uma revolução social com uma alma politica"; com isso também lhe revelamos o segredo de porque ele não consegue, mesmo nos seus torneios estilísticos, elevar-se para além do limitado ponto de vista político. Uma revolução "social" com uma alma política ou é um completo absurdo, se o "prussiano" entende por revolução "social" uma revolução "social" contraposta a uma revolução política e apesar de tudo confere à revolução social uma alma política, além de social, ou, então, uma "revolução social com uma alma política" não é mais do que uma paráfrase do que já se chamou uma "revolução política" ou "simplesmente uma revolução". Toda revolução dissolve a velha sociedade; neste sentido é social. Toda revolução derruba o velho poder; neste sentido é política. Que o "prussiano" escolba entre a paráfrase e o absurdo! Contudo, se é parafrásico ou absurdo uma revolução social com uma alma política, é racional, ao contrário, uma revolução política com uma alma social. A revolução em geral - a derrocada do poder existente e a dissolução das velhas relações - é um ato político. Por isso, o socialismo não pode efetivar-se sem revolução. Ele tem necessidade desse ato político na medida em que tem necessidade da destruição e da dissolução. No entanto, logo que tenha início a sua atividade organizativa, logo que apareça o seu próprio objetivo, a sua alma, então o socialismo se desembaraça do seu revestimento político . (MARX, 1995:s/p)

Assim, nessas passagens finais das Glosas críticas, Marx demarca a concepção de que a solução das contradições presentes no seio da sociedade civil, e na relação desta com o Estado, passa necessariamente pelo "desembaraço do revestimento político" da revolução - o que significa dizer: pela extinção do Estado. Conforme indicado, de acordo com Marx, dada sua configuração necessária na sociedade moderna, o Estado, a "administração", nada podem fazer além de adotar medidas de caráter paliativo e assistencial para enfrentar problemas de ordem estrutural. Por isso, o sentido último do pensamento político de Marx, anunciado em suas primeiras obras, conservado e refinado na sequência de seu trajeto intelectual, se encaminha na contracorrente 
A formação do pensamento político de Marx: crítica a Hegel, emancipação humana e fim do estado

da tradição moderna: não tem como meta final um aprimoramento do aparelho estatal - esforço de efeito inevitavelmente anódino - mas seu desaparecimento ${ }^{20}$. A implicação deste gesto é da maior relevância: afinal, trata-se de reincorporar a esfera política na sociedade, eliminando de fato a oposição do indivíduo frente a esta, na medida em que esta oposição artificial é, como assinalado anteriormente, sobretudo na crítica aos droits de l'homme de $A$ questão judaica, fruto da racionalidade específica da era burguesa.

Diante disso, no entanto, seria legítimo ainda indagar de que modo seria possível levar a cabo essa revolução, isto é: como extinguir o Estado e reabsorver a política na vida imediata, prática, dos sujeitos humanos, realizando sua emancipação?

Como dito anteriormente, Hegel, em sua Filosofia do Direito, apontava que as necessidades sempre crescentes no seio da sociedade civil jamais poderiam ser plenamente satisfeitas, mas apenas minimizadas pela intervenção estatal ou pelo colonialismo. É exatamente esse o diagnóstico marxiano, conforme se depreende, por exemplo, do texto das Glosas. Ocorre que, para aquele filósofo, o fenômeno de ampliação das carências é racional, quer dizer, um momento do processo de realização da Ideia. Não por acaso, a sociedade civil é ali definida como "sistema de carências" - e não como domínio de produção das carências. Ora, retornando à Crítica da Filosofia do Direito de Hegel, o que Marx rejeita, neste ponto, é justamente essa "racionalização" da miséria.

Com efeito, para Marx, seria preciso, antes de incluir a miséria em uma construção racional que a "justificasse", encontrar as condições históricas que a fazem surgir, do mesmo modo que a crítica da religião precisa se ocupar das condições que a alimentam. À luz dessa perspectiva, Marx reconhece em Hegel a percepção de procurar verter o contexto histórico alemão através do pensamento. Contudo, o faz com a ressalva de que, em política, "os alemães pensaram o que outros povos fizeram. A Alemanha foi a sua consciência teórica" (MARX, 2005: 151). Destarte, o problema resultante da análise conceitual hegeliana referente ao Estado moderno seria a abstração do ser humano real: "O status quo do sistema político Alemão exprime a consumação do ancien régime, o cumprimento do espinho na carne do Estado moderno" (MARX, 2005: 151).

Logo, a dúvida que se avizinha é saber se existiria, na Alemanha, a possibilidade daquela aventada emancipação humana para além de sua consciência teórica. Segundo Marx, a resposta seria positiva, e encontrada

na formação de uma classe que tenha cadeias radicais, de uma classe na sociedade civil que não seja uma classe da sociedade civil, de um estamento que seja a dissolução de todos os estamentos, de uma esfera que possua caráter universal porque seus sofrimentos são universais e que não exige uma reparação particular porque 0 mal que the é feito não é um mal particular, mas o mal em geral, que já não possa exigir um titulo histórico, mas apenas o título bumano; de uma esfera que não se oponha a consequências particulares, mas que se oponha totalmente aos pressupostos do sistema politico alemão; por fim, de uma esfera que não pode emanciparse a si mesma nem se emancipar de todas as outras esferas da sociedade sem emancipálas a todas - o que é, em suma, a perda total da humanidade, portanto, só pode 
redimir-se a si mesma por uma redenção total do homem. A dissolução da sociedade, como classe particular, é o proletariado. (MARX, 2005: 155-6)

Afinal, se, como entendia Hegel, a propriedade é a primeira das qualidades de uma pessoa livre, o proletário nem é livre, nem é uma pessoa, pois não tem propriedade $^{21}$. No mesmo diapasão, se as práticas da arte, da religião e da filosofia, isto é, o acesso à Cultura, é o que permite a tomada de consciência do ser humano e do Espírito, então o trabalhador assalariado está inexoravelmente afastado desta possibilidade, pois sua função social não lhe concede tempo para se deleitar naquelas atividades ${ }^{22}$ (como, de resto, o próprio Hegel também reconheceu na Filosofia do Direito). O destino do proletariado, destarte, não é o de realizar as potencialidades humanas. Por isso, nota Marx, sua existência atestaria na prática a não realização do ideal hegeliano: a existência do proletariado "dá testemunho vivo de que a verdade não foi realizada" (MARCUSE, 2004: 228). A tomada de consciência dessa situação alienante seria o primeiro passo no caminho da dissolução da própria sociedade que dá origem ao proletariado.

A tomada de consciência não é a reflexão passiva sobre um estado de coisas, mas é a unica coisa que pode constituir a realidade da contradição dialética, tanto quanto exigir sua resolução. Que o proletariado tome consciência da alienação bumana, significa uma oposição interior ao próprio homem, e essa oposição é contradição real e exigência de resolução apenas porque ela é ao mesmo tempo objetiva e subjetiva, porque ela exprime um estado de fato - o ser bumano posto para fora de si mesmo, como uma coisa -, e uma negação desse fato - o homem como sujeito alienável que precisamente não pode se encontrar como uma coisa. O proletariado, em Marx, é o sujeito que leva ao extremo a contradição da condição bumana e também se torna capaz de resolvê-la. (HYPPOLITE, 1955: 141).

\section{Considerações finais}

Enfim, o pensamento político de Marx molda-se a partir da crítica a Hegel, desde o prisma de que esta filosofia seria a expressão definitiva do ideal da sociedade burguesa (em particular, da realidade alemã). Nesse sentido, Marx denuncia a falácia da autonomia da esfera estatal enquanto polo de superação das cisões sociais, tal como apregoada pelo idealismo hegeliano, desvelando a ligação intrínseca entre a moderna forma de Estado e a sociedade burguesa, isto é, a economia capitalista.

Bem entendida, essa posição não implicará reduzir a esfera política às determinações econômicas - como as leituras "economicistas" de Marx, por vezes amparada em algumas passagens de suas obras, defendem -, mas compreender o vínculo dialético que as une. Afinal, como será dito mais tarde, contra o "materialismo intuitivo" feuerbachiano, que "não apreende a sensibilidade como atividade prática", limitando-se a intuir "os indivíduos singulares e a sociedade civil", o materialismo histórico, que começa a se esboçar nos escritos aqui tratados, adota o ponto de vista "[da] sociedade humana ou [da] humanidade social" (cf. MARX \& ENGELS, 1991: 14). Com efeito, se "o concreto é concreto porque é a síntese de muitas determinações, isto é, unidade do diverso" (MARX, 1999: 39), apenas por um prisma "que integra os diferentes fatos da vida social (enquanto elementos do desenvolvimento histórico) numa totalidade, é que o conhecimento dos fatos se torna possível enquanto conhecimento 
A formação do pensamento político de Marx: crítica a Hegel, emancipação humana e fim do estado

da realidade" (LUKÁCS, 2003: 76). É justamente a "unidade concreta do todo" (LUKÁCS, 2003: 72) que confere sentido à dialética de Marx, e é à luz "perspectiva da totalidade" que as linhas de força de seu pensamento político, moldadas em seus escritos iniciais, devem ser consideradas e servir de horizonte para o tratamento do tema. De fato, para Marx, a autonomia completa de qualquer esfera da vida social nada mais seria do que a aparência ilusória de uma realidade forçosamente totalizante, e, ipso facto, indissoluvelmente articulada - mas jamais redutível mecanicamente a um plano particular ${ }^{23}$. Por isso, se, por um lado, o Estado moderno se ergue sobre as contradições da sociedade civil, isto é, do modo de produção capitalista, por outro, a dominação de classe que ele assegura jamais pode ser compreendida divorciada das inúmeras mediações que, de resto, a própria luta política em seu interior - a luta de classes - constrói.

Além disso, ao apontar naquela direção, ato contínuo, Marx anuncia a necessidade de reincorporar a esfera do universal no particular, isto é, superar concretamente a contradição entre ambos, como meio de reconciliar o ser humano consigo mesmo, superando a alienação em curso. Ou seja, extinguir o aparato estatal como polo separado da vida material do conjunto dos indivíduos, enquanto requisito imprescindível para uma verdadeira emancipação da humanidade - a mesma prometida, mas não integralmente realizada, pela modernidade e os droits de l'homme. Bem entendido, é este o sentido da "verdadeira democracia" ou do comunismo que, até o fim, demarcarão o horizonte prático das aspirações marxianas. $\mathrm{E}$ é, afinal, nessa direção que, recusando o nexo dialético da especulação hegeliana, Marx se direcionará, enxergando na crítica da economia politica um novo nexo que lhe permitirá aprofundar a análise do conjunto da sociedade burguesa - enquanto um todo estruturado - a partir de uma dialética materialista.

\section{Referências bibliográficas}

COLLIN, Denis. Comprender Marx. Trad. Jaime Clasen. Petrópolis: Editora Vozes, 2008.

HEGEL, G. W. F. Filosofia da História. $2^{\mathrm{a}}$ edição. Trad. Maria Rodrigues e Harden. Brasília: Editora da UnB, 1999.

- Principios da Filosofia do

Direito. Trad. Orlando Vitorino. São Paulo: Martins Fontes, 1997.

HYPPOLITE, J. Études sur Marx et Hegel. Paris: Librairie Marcel Rivière, 1955.

- Introducão à filosofia da bistoria de Hegel. Trad. José Marcos Lima. Rio de Janeiro: Elfos ; Lisboa : Edições 70, 1995.

LENIN, V. I. O estado e a revolucão. In: Col. Bases. Trad. Javert Monteiro. Introdução José Paulo Netto. São Paulo: Global Editora, 1987.

LUKÁCS, G. História e consciência de classeestudos sobre a dialética marxista. Trad. Rodnei Nascimento. Revisão Karina Jannini. São Paulo : Martins Fontes, 2003.

MARCUSE, H. Razão e revolução - Hegel e o advento da teoria social. $5^{\text {a }}$ edição. Trad. Marilia Barroso. São Paulo : Paz e Terra, 2004. 
MARX, K. Crítica da filosofia do direito de Hegel. Trad. Rubens Enderle e Leonardo de Deus. São Paulo: Boitempo, 2005.

- Glosas criticas marginais ao artigo 'O rei da Prússia e a reforma social'. De um prussiano. Trad. Ivo Tonet. In: Revista Praxis, Belo Horizonte: Projeto Joaquim de Oliveira, $\mathrm{n}^{\circ}$ 5, 1995 [online]. Disponível em: https:// www.marxists.org/portugues/marx/ $\underline{1844 / 08 / 07 . h t m}$

. Grundrisse. Trad. Mário Duayer e Nélio Schneider. São Paulo: Boitempo, 2011.

Para a crítica da economia política. In: Col. Os Pensadores. Trad. Edgard Malagodi. São Paulo: Ed. Nova Cultural, 1999.

Sobre a questão judaica - inclui as cartas de Marx a Ruge publicadas nos Anais Franco-Alemães. Apresentação e posfácio Daniel Bensaïd. Tradução Nélio Schneider [Tradução de Daniel Bensaïd, Wanda Caldeira Brant]. São Paulo: Boitempo, 2010.

MARX, K. \& ENGELS, F. A ideologia alemã. $8^{a}$ edição. Trad. José Carlos Bruni e Marco Aurélio Nogueira. São Paulo: Editora Hucitec, 1991. - Manifesto do partido comunista (1848) seguido de Gotha. Trad. Sueli Tomazini Barros Cassal. Porto Alegre: L\&PM Editores, 2001.

MENDES, V. A. "A sociedade civil em Hegel e Marx". Emancipação, Ponta Grossa, 12(2), p. 235-252, 2012.

${ }^{1}$ Email: vsantos1985@gmail.com. Como as notas são muito longas, excepcionalmente adotamos o modelo notas de fim. Nota do editor.

Revista de Filosofia Moderna e Contemporânea

Brasília, vol 4, n 1, 2016. 


\section{A formação do pensamento político de Marx: crítica a Hegel, emancipação humana e fim do estado}

$2 \mathrm{Ou}$, como observa Valdenésio Mendes, “essa afirmação é emblemática por dois motivos: primeiro, porque reconhece o trabalho teórico de Feuerbach, denunciando a alienação religiosa, em segundo lugar, porque essas críticas religiosas contêm em germe os pressupostos para estendê-la ao campo da política" (MENDES, 2012: 245).

${ }^{3}$ Em carta a Arnold Ruge, de 1843, Marx já demarcava: “é trazer o velho mundo inteiramente à luz do dia e dar uma conformação positiva ao novo mundo" (In: MARX, 2010: 69).

${ }^{4}$ Mais tarde, nos Grundrisse, Marx dirá a respeito da tese geral do contratualismo moderno: "Indivíduos produzindo em sociedade - por isso, o ponto de partida é, naturalmente, a produção dos indivíduos socialmente determinada. O caçador e o pescador, singulares e isolados, pelos quais começam Smith e Ricardo, pertencem às ilusões desprovidas de fantasia das robinsonadas do século XVIII, ilusões que de forma alguma expressam, como imaginam os historiadores da cultura, simplesmente uma reação ao excesso de refinamento e um retorno a uma vida natural mal-entendida. [...]. Trata-se, ao contrário, de uma antecipação da 'sociedade burguesa', que se preparou desde o século XVI e que, no século XVIII, deu largos passos para a sua maturidade [...]. // Quanto mais fundo voltamos na história, mais o indivíduo, e por isso também o indivíduo que produz, aparece como dependente, como membro de um todo maior: de início, e de maneira totalmente natural, na família e na família ampliada em tribo [stamm]; mais tarde, nas diversas formas de comunidade resultantes do conflito e da fusão das tribos. Somente no século XVIII, com a 'sociedade burguesa', as diversas formas de conexão social confrontam o indivíduo como simples meio para seus fins privados, como necessidade exterior. Mas a época que produz esse ponto de vista, o ponto de vista do indivíduo isolado, é justamente a época das relações sociais (universais desde esse ponto de vista) mais desenvolvidas até o presente. O ser humano é, no sentido mais literal, [...] não apenas um animal social, mas também um animal que somente pode isolar-se em sociedade. A produção do singular isolado fora da sociedade [...] é tão absurda quanto o desenvolvimento da linguagem sem indivíduos vivendo juntos e falando uns com os outros" (MARX, 2011: 39-40).

5 Sendo as palavras de Eric Weil: "Há conhecimento do Estado tal como ele é em si mesmo, conhecimento de uma ideia de Estado, mas de uma ideia que difere da ideia platônica por ser histórica, por não ser uma ideia fora do devir, mas uma ideia do devir, conquanto seja conhecimento objetivo, conhecimento que não deve ocupar-se de sentimentos, de opiniões, de desejos, senão na medida em que esses sentimentos conduzem à ação e formam assim a realidade, conhecimento que não deve tomar posição senão em favor da verdade. Que isso não queira dizer, que isso não possa querer dizer que qualquer Estado é o Estado perfeito, que qualquer Estado tem razão em tudo o que faz, que o indivíduo sempre tem de ter obediência cega [...] a lei, se é realidade no sentido mais forte, é também a realidade menos estranha ao homem: na concepção hegeliana, toda a história é esta reconciliação entre o indivíduo e o universal. // [...] O Estado empírico pode ser imperfeito, e nem tudo é sempre o melhor no melhor dos mundos; o direito positivo pode não ser razoável, o Estado concreto pode ser ultrapassado pela história. Permanece a verdade simples de que não se pode dizer nada de válido antes de saber de que se fala, de que não se pode julgar os Estados sem saber o que é o Estado" (WEIL, 2011: 35-7).

6 “O importante é que Hegel, por toda parte, faz da Ideia o sujeito e do sujeito propriamente dito, assim como da 'disposição política', faz o predicado. O desenvolvimento prossegue, contudo, sempre do lado do predicado" (MARX, 2005: 32).

${ }^{7}$ Com efeito, "o Estado se produz a partir da multidão, tal como ela existe na forma dos membros da família e dos membros da sociedade civil" (MARX, 2005: 31). 
${ }^{8}$ Esses parágrafos - que, como assinalado, apontam um elemento capital da crítica marxiana a Hegel - já prenunciam um passo decisivo no desenvolvimento do materialismo histórico: se a política e a História, em Hegel, servem à demonstração da lógica dialética, Marx procederá de maneira antagônica: trata-se de elaborar uma "história sem pressupostos", que parta apenas dos "indivíduos reais, sua ação e suas condições materiais de vida, tanto aquelas por eles já encontradas, como as produzidas por sua própria ação" (MARX \& ENGELS, 1991: 26). Com efeito, "esta concepção da história consiste, pois, em expor o processo real de produção, partindo da produção material da vida imediata" (MARX \& ENGELS, 1991: 55). Assim, é a partir deste princípio - e não como um desdobramento da Lógica - que a dialética materialista se revela.

${ }^{9}$ Por exemplo, $c f$. HEGEL, 1997: 208-210, §241-246.

10 Recorremos novamente a Eric Weil: "A essência do Estado é a lei, não a lei do mais forte, a lei do capricho, a lei da 'generosidade natural', mas a lei da razão em que todo ser racional pode reconhecer sua própria vontade racional. É verdade que o Estado se apresenta nas esferas do direito privado, da família e até da sociedade do trabalho como uma necessidade exterior, como um poder superior; mas, 'por outro lado, é para eles fim imanente, tendo a sua força na unidade do seu último fim universal e dos interesses particulares do indivíduo; esta unidade exprime-se em terem aqueles domínios deveres para com o Estado na medida em que também têm direitos' (\$261)" (WEIL, 2011: 61).

${ }_{11}$ Marx, de fato, denuncia as mediações lógicas de Hegel, incapazes de resolver efetivamente as contradições reais. Na verdade, como nota Jean Hyppolite, Hegel "se acomoda suficientemente bem nessa tensão na mediação" (HYPPOLITE, 1955: 138).

${ }^{12}$ Como novamente esclarece Hyppolite, para Hegel, no mundo moderno, apenas o regime monárquico poderia promover a unidade entre vida pública e vida privada que, no mundo antigo, a democracia havia realizado - e que é, para Hegel, o sentido último de liberdade; portanto, a "matéria" do próprio Espírito: "Por outras palavras, nas democracias antigas, a vida privada e a vida pública não se opunham verdadeiramente. A liberdade do homem privado não existia, mas, em contrapartida, a verdadeira liberdade, a liberdade do cidadão formulando para si mesmo as suas leis, constituindo a vontade geral, era a alma da cidade antiga. Tal democracia já não é possível; Hegel mostra-lo-á de novo na Fenomenologia, a propósito da Revolução Francesa. No mundo moderno, o homem privado, o proprietário, o burguês, ganharam demasiada importância para serem ao mesmo tempo cidadãos. É por isso que o universal e o singular se opõem na realidade, em vez de se confundirem harmoniosamente, como no mundo antigo. Assim sendo, o governo deixa de ser a expressão de todos, surge como tendo existência independente, é o monarca, e mesmo o monarca hereditário, dado que a natureza desempenha o seu papel nesta oposição, ela é a forma desta existência independente. Há, pois, uma separação entre os governantes e os governados, que é característica do Estado moderno e que se exprime na constituição monárquica; mas entre os dois extremos, o monarca e os súditos, a unidade do todo subsiste. O ideal moderno é a 'universalidade na perfeita liberdade e independência dos indivíduos'. O indivíduo é livre, procura o seu interesse privado, ele próprio escolhe a sua situação, desenvolve-se para si mesmo; por outro lado, o monarca encarna a lei, é a lei viva, o Estado realizado sob a forma de uma vontade pessoal. Mas a unidade do todo, o universal, é conservada, porque a 'liberdade privada' concedida ao indivíduo é a força e a astúcia do Estado, que se coloca acima dos interesses //privados e os dissolve nele. A democracia encontra-se, portanto, ultrapassada, dado que no mundo moderno arriscar-se-ia a mais não ser do que uma dissolução completa do Estado nos interesses privados. Isso foi visível durante a Revolução Francesa, em que, depois de desaparecidos todos os corpos intermédios, ficaram apenas em presença a vontade particular e a vontade geral. Mas a dominação da vontade particular gerou a anarquia e a manutenção da vontade geral exigiu o Terror" (HYPPOLITE, 1995: 99-100). 


\section{A formação do pensamento político de Marx: crítica a Hegel, emancipação humana e fim do estado}

13 Vale aqui destacar a observação feita por Rubens Enderle, na apresentação da edição brasileira da Crítica da Filosofia do direito de Hegel: "É preciso, porém, distinguir, na argumentação marxiana os dois níveis em que o termo democracia é empregado: como 'gênero' (a 'verdadeira democracia') e como 'espécie' (a 'república política'). A 'verdadeira democracia' é um princípio político, não um Estado existente. Ela significa a realização plena do Estado como universal concreto, a verdadeira superação da oposição entre Estado político e sociedade civil. Na verdadeira democracia, diz Marx, 'o Estado político desaparece', assim como também desaparece o Estado não político, isto é, a sociedade civil. Com o termo 'república política', Marx se refere à democracia no interior do 'Estado abstrato', à democracia existente, ainda não plenamente realizada. Nesse Estado, embora a constituição ainda seja política, ela não é mais 'simplesmente política', o que significa que o conteúdo genérico, político, já começa a penetrar as esferas não políticas” (ENDERLE. In: MARX, 2005: 24).

${ }^{14}$ A solução de Marx à contradição "que não está apenas no pensamento de Hegel, mas que efetivamente exprime um momento da história" é a "absorção do Estado na sociedade, essa sociedade transformandose a si mesma para não mais se perder do atomismo individualista” (HYPPOLITE, 1955: 126).

${ }^{15}$ Contudo, vale fazer a ressalva de que Marx jamais elaborou uma doutrina completa e unitária acerca do Estado, o que impede essa assimilação imediata entre Estado e dominação classista - ao contrário do que acreditava Lênin, por exemplo, em uma visão que seria consagrada ao longo de quase todo o século XX. Com efeito, em $O$ estado e a revolução, Lênin, parte do pressuposto da existência de uma teoria do Estado em Marx (por conseguinte, uma teoria política específica), o que, como observa José Paulo Netto, "não encontra suporte explícito em Marx" (NETTO. In: LENIN, 1987: 44 - prefácio). Marx, na verdade, trata do tema em escritos esparsos e de diferentes envergaduras (de panfletos políticos a tratados científicos ou filosóficos propriamente ditos). Em segundo lugar, porque essa suposta teoria - que Lênin toma como existente a partir de uma coleção arbitrária de passagens dos escritos marxianos -, é apresentada mediante uma aproximação das concepções de Engels sobre a origem do Estado - de teor histórico-antropológico, e notadamente marcadas pelo evolucionismo teórico - daquelas de Marx centradas quase que exclusivamente na análise do funcionamento específico do Estado moderno, constituinte do modo de produção capitalista. A validade desse agenciamento, no ponto em questão, é, no mínimo, duvidosa. Ademais, como também observa Netto, Lênin, em O estado e a revolução, ignora textos marxianos importantes da década de 1840, aos quais ele certamente teve acesso (como a Introdução à Crítica da filosofia do direito de Hegel), e jamais se remete a $O$ capital. O impacto dessa negligência é destacado: "Parece inconteste que, em Marx (e em Engels), o Estado é um instrumento de domínio de classe - das fórmulas do Manifesto do partido comunista (e mesmo antes delas) ao fim dos seus dias, Marx enfatizou decisivamente esta caráter do Estado, a que se prendem as determinações da violência e da ditadura. Em Marx, porém, o domínio de classe não se exerce apenas através da coerção aberta ou, mais exatamente, o Estado não é, sempre e/ou necessariamente, a configuração direta e imediata de uma vontade política de classe. Se, em alguns textos redigidos especialmente para atender a uma demanda política conjuntural ou para estabelecer consignas de entendimento rápido e massivo (aquilo a que o próprio Lênin chamou 'propaganda' e 'agitação'), a formulação marxiana apresenta assim a essência do Estado [como no Manifesto comunista - V.S.], é evidentemente um equívoco restringir a tais formulações a concepção que Marx tem do Estado moderno (burguês) esta comporta toda uma série complexa de mediações, envolvendo mesmo a representação e o mais que ela importa. O domínio de classe (ditadura) que o Estado moderno (burguês) compulsoriamente realiza, pois, não é nem unidimensional, nem direto" (NETTO. In: LÊNIN, 1987: 30-1 - prefácio).

Revista de Filosofia Moderna e Contemporânea

Brasília, vol 4, no 1, 2016. 
16 “Na Alemanha, onde não existe um Estado político, onde não existe o Estado como Estado, a questão judaica é uma questão puramente teológica. O judeu encontra-se em oposição religiosa ao Estado que confessa o cristianismo como sua base. Esse Estado é teólogo ex professo [com perfeição]. Nesse caso, a crítica que se faz é a crítica à teologia, crítica de dois gumes, crítica à teologia cristã, crítica à teologia judaica. Entretanto, por mais que estejamos nos movendo criticamente, ainda estamos nos movendo no interior da teologia. Na França, no Estado constitucional, a questão judaica é a questão do constitucionalismo, a pergunta referente à parcialidade da emancipação política. Como ali se mantém a aparência de uma religião do Estado, ainda que numa fórmula inexpressiva e autocontraditória, a saber, na fórmula da religião da maioria, a relação entre os judeus e o Estado conserva a aparência de um antagonismo religioso, teológico. Os estados livres norte-americanos - ao menos em uma parte deles foram o único lugar em que a questão judaica perdeu seu sentido teológico e se tornou uma questão realmente secular. Só onde o Estado político existe em sua forma plenamente desenvolvida, a relação do judeu, e de modo geral do homem religioso, com o Estado político, ou seja, a relação entre a religião e o Estado, pode emergir em sua peculiaridade, em sua pureza. A crítica a essa relação deixa de ser uma crítica teológica no momento em que o Estado deixa de comportar-se teologicamente para com a religião, no momento em que ele se comporta como Estado, isto é, politicamente, para com a religião. A crítica transforma-se, então, em crítica ao Estado político. Justamente no ponto em que a questão deixa de ser teológica, a crítica de Bauer deixa de ser crítica” (MARX, 2010: 37).

17 “[A] revolução política que derrubou esse poder do soberano e alçou os assuntos de Estado à condição de assuntos de toda a nação, que constituiu o Estado político como assunto universal, isto é, como Estado real, desmantelou forçosamente o conjunto dos estamentos, corporações, guildas, privilégios, que eram outras tantas expressões da separação entre o povo e seu sistema comunitário. Desse modo, a revolução política superou o caráter político da sociedade burguesa. Ela decompôs a sociedade burguesa em seus componentes mais simples, ou seja, nos indivíduos, por um lado, e, por outro, nos elementos materiais e espirituais que compõem o teor vital, a situação burguesa desses indivíduos” (MARX, 2010: 52).

${ }^{18}$ Uma das passagens mais felizes do pensamento político hegeliano, vale insistir, é seu diagnóstico da contradição entre o aumento da riqueza produzida pela sociedade moderna, de um lado, e o crescimento de uma massa de miseráveis, de outro (cf. novamente HEGEL, 1997: 206-10, §241-246, especialmente o $\S 245)$.

19 Ao afirmar que a essência humana é a verdadeira comunidade humana, Marx mais uma vez assinala, conquanto desta vez não em termos políticos (como está implícito nos textos analisados neste artigo), mas “ontológicos", a temática da alienação, que seria aprofundada nos Manuscritos econômico-filosóficos, também de 1844, e que é absolutamente central para a compreensão da totalidade de seu pensamento.

${ }^{20}$ Nesse sentido, a partir do anti-estatismo de fundo presente no pensamento de Marx, torna-se legítimo encarar sua filosofia e sua política como "herdeiros, sem dúvida críticos, mas não como negadores da tradição liberal” (MANACORDA, apud MENDES, 2012: 250).

21 Para Hegel, o Reino do Direito como o Reino da Liberdade. A liberdade é a "ideia do direito", concretizada na imposição da vontade do indivíduo como uma liberdade de apropriação: "Tem o homem o direito de situar a sua vontade em qualquer coisa; esta torna-se, então, e adquire-a como fim substancial (que em si mesma não possui), como destino e como alma, a minha vontade. É o direito de apropriação que o homem tem sobre todas as coisas." (HEGEL, 1997: 46, §44). Mas essa liberdade de apropriação se efetiva, de fato, quando se reconhece enquanto tal, ou seja, quando o indivíduo a põe à prova, impedindo que outros desejem os objetos de sua vontade, que, então, tornam-se exclusivamente seus - e assim é reconhecido pelos demais: "É a minha vontade pessoal, e portanto como individual, que se torna objetiva para mim na propriedade; esta adquire por isso o caráter de propriedade privada, e a propriedade comum, que segundo a sua natureza pode ser ocupada individualmente, define-se como uma comunidade virtualmente dissolúvel e na qual só por um ato do meu livre-arbítrio eu cedo a minha parte" (HEGEL, 1997: 45, § 46). Mas, como visto, a determinação lógica do conceito de Direito só se efetiva plenamente no Estado, uma vez que a "naturalidade" do Direito implica na instituição de uma segunda natureza, de ordem ética e política, tornando a ideia do Direito de "reino da liberdade efetiva".

Revista de Filosofia Moderna e Contemporânea

Brasília, vol 4, n 1, 2016. 


\section{A formação do pensamento político de Marx: crítica a Hegel, emancipação humana e fim do estado}

${ }^{22} C f$. MARCUSE, 2004: 227.

23 Esta questão, naturalmente, merece maior atenção do que aquela que pode ser aqui dispensada. Por um lado, é verdade que algumas passagens de Marx podem legitimar uma leitura "economicista". Basta se lembrar, por exemplo, de excertos de A ideologia alemã, da definição presente no Manifesto comunista de que o governo moderno "é tão somente um comitê que administra os negócios comuns de toda a classe burguesa" (MARX \& ENGELS, 2001, p. 27), ou da metáfora base/superestrutura exposta no Prefácio da Contribuição à crítica da economia política. Por outro lado, no entanto, textos como $O 18$ Brumário de Luís Bonaparte, no qual Marx explora tanto a relação entre os camponeses parcelares e sua "representação" política na figura do sobrinho de Napoleão, quanto as fraturas internas no seio da própria burguesia; ou As lutas de classe na França de 1848-1850, inclusive a Introdução escrita por Engels em 1895, que sinalizam nuances na análise do Estado e da política, cujo refinamento torna-se incompatível com a tese economicista. Para o propósito desse artigo basta indicar a validade de se supor que a perspectiva de que o Estado moderno assenta-se sobre as contradições da sociedade burguesa - Marx jamais abrirá mão dessa ideia - não implica em um reducionismo economicista. Ainda que aquele seja seu sentido último - o que poderia justificar as passagens de Marx que respaldariam essa visão -, é também na esfera estatal delimitada pela era burguesa que, segundo o filósofo, mudanças favoráveis à "emancipação humana" poderiam se concretizar (vide o oitavo capítulo de $O$ Capital, no qual o autor trata da luta política pela redução da jornada de trabalho; ou textos como Salário, preço e lucro ou a Crítica do programa de Gotha). Desse modo, nem autonomia (ao modo hegeliano), nem economicismo: ao fim e ao cabo, entendemos que o pensamento de Marx busca desvendar o caráter de tensão existente entre os domínios, aparentemente separados (autônomos), da sociedade civil e do Estado, a partir de uma articulação histórico-dialética de ambos.

De todo modo, inegavelmente, essa questão exige um tratamento mais aprofundado. Como sugestão ao leitor interessado, porém, podemos indicar a Parte V do trabalho de Dennis Collin, Compreender Marx, como uma introdução a este problema (cf. COLLIN, 2008, p. 227 e ss.). 